\title{
500 ANOS DE REFORMA PROTESTANTE E A (IN)JUSTIÇA SOCIAL
}

\begin{abstract}
RESUMO: Em 2017 completaram-se 500 anos da reforma protestante, data que se toma como referência a emblemática proposta de reforma de Martinho Lutero pregada nas portas da Catedral de Wittemberg. 0 presente trabalho reside em questionar e revisar os avanços no que tange a justiça social em nível simbólico e prático, dado que este preceito foi tão fundamental a este movimento e seus pensadores/reformadores. Para tal, inicialmente, buscou-se analisar do ponto de vista comparativo com as perspectivas bíblicas o conceito de justiça social, utilizando como exemplos textos veterotestamentários e, excertos do novo testamento. Em seguida, a pesquisa observou nos fundamentos ensinados pelos reformadores, focando apenas em dois mais relevantes, a saber, Martinho Lutero e João Calvino e, por fim, avaliou-se de que forma as Igrejas Protestantes atuais têm contribuído com os menos favorecidos socialmente, ou seja, almejou-se avaliar os pontos de continuidade e ruptura no contexto das Igrejas Protestantes desde a gênese da reforma.
\end{abstract}

PALAVRAS-CHAVE: Justiça social; Reforma protestante; História da igreja.

\section{YEAR OF THE PROTESTANT REFORMATION AND SOCIAL (IN)JUSTICE}

\begin{abstract}
Five hundred years have passed since the Protestant Reformation. Reference date 1517 is emblematic to mark Martin Luther's posting of his propositions on the door of Wittenberg's Cathedral. Current paper questions and reviews progress in social justice at the symbolical and practical levels. The precept was basic to the Reformation and its protagonists. The concept of social justice is first analyzed from the Biblical point of view, employing Old and New Testament texts. Research reviewed the reformers' basic teachings, focusing on the works by Luther and Calvin. It also discusses the manner current Protestant Churches contributed towards the poor and destitute, or rather, evaluates the continuity and rupture themes within the context of the reformed churches since the Reformation.
\end{abstract}

KEYWORDS: Social justice; Protestant reformation; History of the Church.

\section{INTRODUÇÃO}

Como balizador e norteador da fé cristã, a Bíblia tem ensinamentos simples e práticos a respeito da assistência às necessidades da sociedade. Grande parte dessas referências pode ser encontrada na descrição, e estão enraizadas, nos ensinamentos da cultura hebraica. A partir de Milhoranza (2013), entendemos que a integralidade de vida na teologia remonta ao fato de que não podemos adorar a Deus coletiva- mente se alguém passa por algum tipo de injustiça fora do ambiente de culto. Ou seja, o culto a Deus sai da esfera unicamente privada, para um contexto coletivo de adoração.

De acordo com Mackay (1941), o indivíduo pode crer em toda a Bíblia e, infelizmente, não descobrir a verdade fundamental nela contida. Esse pensamento levanta alguns questionamentos mais profundos a respeito da carência de conhecimento de alguns pilares da fé cristã. Essa ignorância seria por inocência

\footnotetext{
Discente do Curso de Teologia, Centro Universitário de Maringá (UNICESUMAR), Brasil. E-mail: enockmeca@yahoo.com.br

** Orientador, Docente Mestre e Coordenador do curso de Teologia EAD, Docente do Centro Universitário de Maringá (UNICESUMAR).

Pesquisador do GAPDH - Grupo de Apoio à Pesquisa e Docência em História. Brasil.
} 
ou por motivos mais torpes? É sabido que grande parte das Igrejas Protestantes têm pastores bivocacionados e, muitos deles, sem formação acadêmica no campo da teologia e havendo, em alguns casos, nem a formação escolar básica. Como, tanto para 0 pastoreio quanto para a profissão de qualquer fé não exigem regulamentação e conhecimento mínimos, 0 crescimento desordenado das Igrejas Protestantes trazem algumas sequelas no tocante a ortodoxia. Para Padilha (1980), a palavra de Deus necessita ser compreendida e ser aplicada no tocante à complexidade das circunstâncias do indivíduo e do mundo. Ele ainda afirma que ao passo que 0 discernimento cultural e tradicional se opõe aos claros preceitos bíblicos, temos um problema, sobretudo, hermenêutico.

0 sociólogo Boaventura Santos (2009) diz que os direitos humanos são, supostamente, uma resposta para os problemas do mundo, resposta que é universalmente válida. Ao pensar em justiça social, entendese que a sua prática nada mais é do que garantir aos seres humanos 0 cumprimento de seus direitos que deveriam ser, a priori, alcançado por todos.

A desigualdade social e a falta de assistência aos menos favorecidos são uma triste e decepcionante marca na sociedade brasileira. Portanto, é salutar analisar de que maneira, após 500 anos de reforma protestante, a injustiça social tem sido combatida no âmbito das Igrejas Protestantes no Brasil. Em especial, esse trabalho visa trazer uma reflexão se as suas comunidades de fé protestantes têm contribuído para o cumprimento dos preceitos bíblicos no tocante a assistência aos menos favorecidos.

0 intuito desse projeto foi fazer uma análise comparativa dos ensinamentos bíblicos percebidos e propagados pelos reformadores no início da Idade Moderna - tendo como foco principal a questão da percepção de justiça social - com as igrejas atuais, buscando assim avaliar uma dialética entre estes dois momentos frente a este tema tão fundamental ao cristianismo.

A pergunta que precisa ser respondida é: "por que com 0 aumento significativo de protestantes no Brasil, nesses 500 anos de reforma, não tiveram uma práxis transformadora, ou seja, uma proposta de mudança de estrutura socioeconômica para a diminuição da injustiça social, uma vez que a bíblia e a teologia protestante orientam sobre a justiça e a diaconia como missão da igreja?"

Como a pesquisa emprega o método bibliográfico, a mesma consiste no levantamento de dados e compilação de informações a partir de: a) pesquisas que contemplem assuntos relativos ao período histórico vetero e neotestamentário; b) pesquisas sobre as origens do movimento protestante e os ensinos dos reformadores; e c) pesquisas que contemplem a atuação das Igrejas Protestantes no tocante a luta por dirimir as injustiças sociais. 0 emprego desse método bibliográfico de pesquisa visou, de maneira simplificada, investigar os aspectos sociais, religiosos e culturais dos períodos supracitados, e, por fim, analisou de forma panorâmica as atividades ligadas ao suporte dos menos favorecidos que as Igrejas Protestantes atuais estão fazendo e comparar com o discurso dos reformadores e dos textos bíblicos.

\section{JUSTIÇA SOCIAL NAS ESCRITURAS SAGRADAS}

Dentre toda a bibliografia pesquisada, é afirmado que a grande mensagem do cânon reflete 0 amor ao próximo e, por consequência, a luta pelo fim de toda e qualquer injustiça. Em especial, o Dr. Shedd (2013) afirma que a injustiça social toma papel de destaque como inimigo do homem e de Deus. Para o doutor, a mesma deve ser combatida ferozmente e, para isso deve-se utilizar todas as armas que estiverem disponíveis e, em sua concepção, a religião é uma das armas mais poderosas.

Para os estudos do Antigo e Novo Testamentos, foi feita uma releitura do cânon com uma chave hermenêutica única (justiça social). A partir daí as conclusões a respeito de cada passagem bíblica foi explicitada. Infelizmente, apenas os textos julgados mais relevantes foram destacados, havendo, sem sombra de dúvidas, muitos outros exemplos. 


\subsection{ANTIGO TESTAMENTO E A JUSTIÇA SOCIAL}

Ao analisar os textos veterotestamentários, vale salientar 0 que Balancin $(1989$, p.7) diz a respeito das características que foram feitas em grande parte desses escritos. Ele afirma que os acontecimentos conservados na Bíblia têm o caráter de "histórias contadas pelo povo", ou seja, passadas de geração em geração sem a necessidade de trazer grandes detalhes, ou ainda não tem 0 intuito de provar que são dados históricos. Entretanto, 0 autor ainda afirma que, apesar de tudo isso, a essência dos acontecimentos é preservada e, o mais importante, os ensinamentos deixados para a posteridade se preserva.

Observam-se nos primeiros 11 capítulos do livro de Gênesis que há verdades teológicas para a preservação da vida e da dignidade humana. Já no capítulo primeiro, percebe-se que na narrativa que a ação do criador é semelhante a um artista que cria uma obra de arte: Deus (0 artista) traz a vida sua obra -prima (o ser humano) e o chama de imago dei, ou seja, imagem de Deus (BÍBLIA, Gn 1.27). Esse conceito antropológico é de suma importância para que o ser humano entenda que ele e qualquer semelhante tem um valor inestimável para a teologia hebraica. Se há o entendimento que todo homem é bëtselem Elohym (imagem de Deus), intuitivamente, o pensar e 0 agir a respeito do outro terão outra conotação: quem compreende e concorda que 0 valor do homem é grande para esta divindade, entende, em última análise, todo 0 ensinamento das escrituras e, por consequência, que nenhuma forma de injustiça deve ser praticada ao outro.

Uma das narrativas mais polêmicas a qual remonta a uma catástrofe natural, 0 autor de Gênesis traz, no capítulo $\mathrm{VI}$, a história de um dilúvio que destruiu a população mundial, restando apenas Noé e sua família. Novamente, o texto bíblico diz que "0 Senhor viu que a perversidade do homem tinha aumentado na terra e que toda a inclinação dos pensamentos do seu coração era sempre e somente para o mal." (BÍBLIA, Gn 6.5). A comunidade hebraica entendia que sua divindade desprezava a maldade humana a ponto de exterminar a sua existência caso fosse necessá- rio. A ideia de um deus que não aceita injustiça segue num famoso episódio que Moisés é chamado para libertar o povo hebreu onde Deus declara que "De fato tenho visto a opressão sobre o meu povo no Egito, [...], por causa dos seus feitores, e sei quanto eles estão sofrendo. Por isso desci para livrá-lo das mãos dos egípcios" (BÍBLIA, Ex 3, 7-8). Ratificando o conceito antropológico de valorização do homem contra as injúrias por ele sofrida.

0 cuidado com o mais necessitado é tido como algo bastante relevante na lei mosaica, tanto que, há uma descrição direta no capítulo XV do livro de deuteronômio:

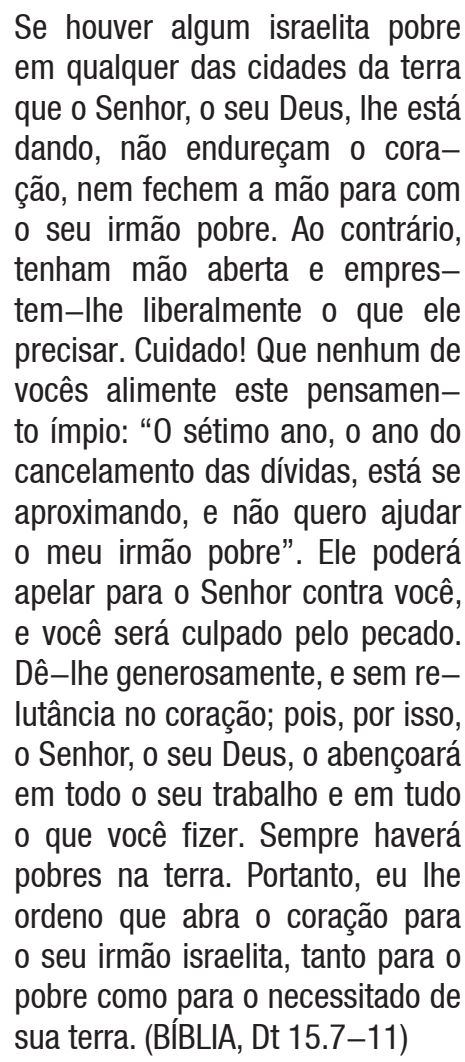

Ou ainda indiretamente, quando tratado no livro de levíticos, no capítulo 23, ao falar sobre "deixar a terra descansar" no sétimo ano, para que os pobres possam se alimentar dos frutos provenientes desse ano. Mais uma vez, o ensinamento para que o mais necessitado tenha acesso a alimento e, por consequência, tenha sua vida preservada é bastante claro nessas passagens.

Outro evento que remonta a um fato ocorrido com o povo hebreu foi sua saída do Egito. 0 povo vivia 
sob o regime escravocrata o qual o Faraó oprimia 0 povo. Ao sair dessa condição, o povo sai para a região de Canaã e, nesse novo lugar, nenhuma das tribos ficou sem ser assistida no novo local de estabelecimento. Balancin (1989) ainda afirma que no novo sistema de governo estabelecido, tinha como objetivo não deixar 0 povo sofrer a mesma opressão outrora vivida no Egito, ou ainda, não manter a injustiça corriqueiramente vivida nas cidades-Eestados da região. Portanto, para isso, essa nova teocracia seria instituída por juízes para uniformizar as leis de cada tribo e, com isso julgar os casos pendentes.

Ao sair do pentateuco e caminhar um pouco mais na Bíblia hebraica, o livro de Salmos traz exortações a respeito do auxílio aos pobres e, como consequência 0 ajudador recebe 0 favor divino: "Como é feliz aquele que se interessa pelo pobre! 0 Senhor o livra em tempos de adversidade." (BÍBLIA, SI. 41.1). Neste Salmo, e em muitos outros, 0 (s) autor (es) declara que Deus ou 0 rei são defensores dos pobres e mantenedores da justiça social (BÍBLIA, SI. 9.9; 10.17-18; 72.1-4).

Ainda nos escritos do Primeiro Testamento, há o Amós que ficou conhecido como "o profeta da justiça social”. Milhoranza (2013) lembra que esse profeta é contemporâneo de Miquéias e Oséias e foi o primeiro dos profetas escritores. Ele recusou ser chamado de profeta e rompeu com as instituições formais do seu tempo (o palácio real e o templo), logo, essa independência institucional o permitiu proclamar a Palavra de Deus sem nenhuma preocupação com retaliações públicas, ou ainda, nenhum interesse escuso. Naquele tempo, tanto Israel quanto Judá gozavam de certa estabilidade política e econômica, entretanto, apenas os comerciantes e a corte usufruíam desse benefício. Em contrapartida, o povo sustentava toda a estrutura por meio da injustiça social e da escravidão. Milhoranza ainda afirma que, cronologicamente, a segunda mensagem de Amós encontra-se nos capítulos 3 a 6 e que nesse excerto " $A$ injustiça social e a falsidade religiosa são condenadas. Amós apela ao povo para que se arrependam e retornem aos padrões da Aliança. A ideia do Dia do Senhor como um dia de bênção também é corrigida." São nesses capítulos que Amós resgata as estipulações da Aliança que incluía, dentre outras coisas, 0 aspecto ético em relação ao próximo como parte do amor a Deus. A partir daí ele apela em favor dos pobres, injustiçados e oprimidos pelos ricos, comerciantes desonestos, líderes corruptos, juízes sem escrúpulos e falsos sacerdotes.

0 Primeiro Testamento, por meio dos escritos do profeta Isaias, enfatiza a necessidade da bondade e honestidade fazer parte do cotidiano da nação. Ao descrever a desonestidade e maldade, a atitude em prol da injustiça e não defender os direitos dos órfãos e das viúvas se sobressaem.

A cidade de Jerusalém era fiel a
Deus, mas agora está agindo como
prostituta. Estava cheia de gen-
te boa e honesta, mas agora só
ficaram assassinos. Seus chefes
são bandidos e sócios de ladrões.
Estão sempre aceitando dinheiro
e presentes para torcer a justiça.
Não defendem o direito dos órfãos
e não se preocupam com as cau-
sas das viúvas (BÍBLIA, Is. 1,21.23).

Esse mesmo autor, no capítulo 10, versos 1 e 2, enfatiza a falta de administração da justiça, em especial a partir daqueles que decretam leis injustas que exploram o povo. Salienta que o direito do pobre, das viúvas e dos necessitados deve ser preservado. É interessante como os escritos desse profeta chegam como ordens tanto as pessoas simples como a magistrados e políticos.

Outro profeta na galeria dos "profetas menores" é o Miquéias. Seus escritos, semelhantes ao do Isaias, também questionam o sistema de governo vigente e condena as injustiças praticadas por ele:

Escutem, líderes e autoridades de Israel! Vocês deviam praticar a justiça e, no entanto, odeiam 0 bem e amam o mal. Vocês tiram a pele do meu povo e arrancam a carne dos seus ossos. Vocês devoram o meu povo: arrancam a pele, quebram os ossos e cortam a carne em pedaços, como se faz com a carne que vai ser cozinhada (BÍBLIA, Mq. 3,1-3). 
Passarella (2014, p.22) afirma que Deus requer justiça aos pobres e, por consequência, julgará os que se opõem a eles. 0 autor se baseia nas palavras do profeta Zacarias: "Executai juízo verdadeiro, mostrai bondade e misericórdia, cada um a seu irmão; não oprimais a viúva, nem o órfão, nem o estrangeiro, nem o pobre." (BÍBLIA, Zc, 7.9-10).

Outro ponto que denota a injustiça no contexto das relações interpessoais é descrita por Ezequiel, ao ressaltar que no capítulo 27, no versículo 12 que alguns israelitas estavam matando por dinheiro, ao passo que outros estavam enriquecendo ao emprestar dinheiro a juros exorbitantes aos seus próprios irmãos. Esse tipo de exploração, desde os escritos veterotestamentários, já era condenada.

A injustiça atinge pessoas reais. Homens e muIheres que têm endereço, família e direito à vida. Mas que, entretanto, Ihe são negados. Quem são as vítimas da injustiça? As vítimas ocupam lugar de relevância na literatura bíblica: 0 indivíduo concreto e sua família aparecem como vítimas dos opressores. Pessoas que foram submetidas à violência e à injustiça e, consequentemente, se tornaram pobres. Os pobres da Bíblia são os pobres reais, em sentido sociológico. Pessoas com menos possibilidade de se realizarem na sociedade, de desenvolver sua criatividade, de ser autônomo e livre.

Os termos abaixo englobam as pessoas que padecem as injustiças das autoridades, a cobiça dos falsos profetas, a corrupção dos que detêm todo tipo de poder. Essas vítimas pertencem sem dúvida à população camponesa, mas não podemos excluir outros grupos, localizados talvez em Jerusalém. São pessoas inocentes, que morrem nas mãos de criminosos (Jr 2,34 ), sem que os reis façam alguma coisa (Jr 22,3); pobre gente despojada de tudo (Jr 5,25-28); imigrantes, órfãos e viúvas oprimidos, sem que ninguém defenda seus direitos (Jr 7,6; 22,3); escravos submetidos aos vaivéns das decisões arbitrárias de seus donos (Jr 34,8-22); operários que devem trabalhar de graça por vontade de um rei injusto (Jr 22,13).

\subsection{NOVO TESTAMENTO E A JUSTIÇA SOCIAL}

Nada mais salutar que iniciar os ensinos neotestamentários com as palavras do Nazareno:
[...] Quando você der um banquete ou jantar, não convide seus amigos, irmãos ou parentes, nem seus vizinhos ricos; se o fizer, eles poderão também, por sua vez, convidá-lo, e assim você será recompensado. Mas, quando der um banquete, convide os pobres, os aleijados, os mancos, e os cegos. (BÍBLIA, Lc 14:12,13).

No excerto acima, fica evidente 0 cuidado especial aos menos favorecidos. Keller (2013, p. 64) explica que, nos dias que Jesus viveu, a sociedade funcionava em sistema de patronagem. Isso queria dizer que pessoas ricas construíam uma rede de influências a qual abria portas e oferecia recursos a pessoas que Ihes proporcionavam oportunidades de negócios, favores políticos etc. Nesse contexto, as festas e banquetes eram uma necessidade que custava muito caro, entretanto, eram nesses ambientes que grandes negócios poderiam ser fechados. Portanto, os banquetes eram um meio de sustentar e recompensar esses relacionamentos já existentes e, é claro, criar outros nos mesmos moldes. Desta forma, qualquer indivíduo apenas convidaria para um baquete seus amigos, conhecidos e vizinhos com elevado padrão financeiro.

De maneira geral, a mensagem do mestre parecia ser um contrassenso econômico-social. 0 que 0 conselho dizia era que os convidados não fossem os amigos de classe social igual ou mais alta que eles, pessoas essas que trariam benefícios financeiros, mas gente pobre e sem influência, que nunca teria a oportunidade de retribuir com dinheiro nem favores. 0 discurso de Jesus se caracterizava pelo ataque ao sistema de patronagem que não era caracterizado por compaixão e nem por justiça. A ética de Jesus era baseada no amor e, por consequência, atacava o sistema vigente em sua origem.

Outro momento que merece atenção foi quando os discípulos de João Batista procuraram Jesus para saber se ele era mesmo o Messias. Em sua resposta ele diz que: "Voltem e anunciem a João 0 que vocês estão ouvindo e vendo: os cegos veem, os mancos andam, os leprosos são purificados, os surdos ouvem, os mortos são ressuscitados, e as boas novas são pregadas aos 
pobres" (BÍBLIA, Mt 11.4,5). Nesses versículos, conclui-se também que as pessoas vulneráveis são objeto de preocupação para Deus. Mesmo Jesus anunciando as boas-novas para todas as pessoas, durante sua passagem na terra, ele revelou que havia um interesse particular pelos pobres e oprimidos.

Keller (2013, p. 62) enfatiza que os leprosos também foram destaque no ministério de Jesus. Eles eram pessoas que estavam à beira da morte e estavam excluídos socialmente. Além de se importar com a cura física deles, Jesus estendeu a mão e tocou nelas, presenteando-as com o primeiro contato humano que recebiam há muito tempo. 0 mestre ainda desafia seus discípulos a ofertarem aos pobres, ao mesmo tempo em que elogiava os pobres pela generosidade (BÍBLIA, Mc 12.42,43).

Outras passagens corroboram ainda com 0 cuidado e atenção que deve ser dada aos pobres: Como na passagem que os discípulos são desafiados a vender os bens e dar esmolas, como recompensa um tesouro no céu estará preparado (BÍBLIA, LC 12.33), ou ainda numa das passagens mais famosas, à qual 0 jovem rico é instruído a vender tudo o que tem e dar aos pobres (BÍBLIA, Mt 19.21). Essa segunda passagem, dita como não prescritiva por alguns, encontra ressonância com a que Zaqueu, cobrador de impostos, ao se converter, afirma que dará metade de suas riquezas aos pobres. Atitude essa aprovada pelo Galileu.

0 livro de Atos é uma apologia ao cuidar social. No final deste livro, Paulo resume, de maneira clara, em suas últimas palavras, algo de extrema valia para ele: "Em tudo o que fiz, mostrei-Ihes que mediante trabalho árduo devemos ajudar os fracos, lembrando as palavras do próprio Senhor Jesus, que disse: "Há maior felicidade em dar do que em receber'" (BÍBLIA, At 20:35). Em outras palavras, Paulo lembra que, mesmo tendo vivido parte de sua vida plantando igrejas, escrevendo cartas e pastoreando um número incontável de pessoas, ele traz à lembrança que há um esforço necessário e imanente ao cristão: ajudar aos mais necessitados. Ele ressalta ainda que essas palavras também foram ditas por Jesus, que a felicidade do verdadeiro cristão estará, sempre, em fazer mais pelo outro do que receber coisas e bens materiais.

Durante a leitura de todo o livro de Atos, é possível ver que não havia necessitados entre eles. Detalhes a respeito dessa vida em comum são relatados em Atos 2.42-47. É, dentro dessa perícope, que se extrai o maior fundamento do termo koinonia:

Vendendo suas propriedades e bens, distribuíam a cada um conforme a sua necessidade. Todos os dias, continuavam a reunir-se no pátio do templo. Partiam o pão em suas casas, e juntos participavam das refeições, com alegria e sinceridade de coração.(BíBLIA, At 2:45,46).

E, como complemento, verificava-se ainda uma generosidade radical, pois as escrituras afirmam que não havia nenhum necessitado entre eles, pois tudo era repartido com qualquer um que tivesse necessidade (BÍBLIA, At 4.34-35.). É incontestável que 0 autor de Atos estava fazendo uma referência ao escrito da Torá em Deuteronômio 15.4. Nos escritos veterotestamentários, os fiéis são chamados a estender a mão aos pobres enquanto houver necessidade, ou seja, até que eles possam cuidar de si.

Por fim, ao analisar o texto da carta aos Gálatas, no capítulo 6 , no verso 10 , Paulo exorta aos cristãos da região da Galácia que "enquanto temos oportunidade, façamos o bem a todos". 0 que deixa explícito que a prática do amor e da luta pela justiça social não deve ficar restrita às pessoas que professam a mesma fé.

\section{A JUSTIÇA SOCIAL E OS REFORMADOES}

Nada mais salutar que, dentre o grande número de reformadores, Lutero e Calvino fossem destaque na análise em questão. Indubitavelmente, os pensamentos provenientes desses teólogos influenciaram (e ainda influencia) a cosmovisão de milhões de pessoas em todo o mundo. Seria ainda interessante abordar a visão de justiça social dos outros reformadores, entretanto, não é o que se propõe a análise da pesquisa em questão. 
A análise, a seguir, mostra como os preceitos já abordados anteriormente nas sagradas escrituras são interpretados por Martinho Lutero e por João Calvino. É muito interessante como, apesar de concordarem no tocante a justiça social como preceito bíblico, eles entendem que a aplicação dessa verdade pode ser efetivada de maneiras diferentes, ou seja, cada um em seu contexto.

\subsection{MARTINHO LUTERO}

Ao abordar algumas virtudes de Deus, Lutero traz a noção que foi o Espírito Santo quem ensinou Maria, a jovem e pobre futura mãe de Jesus, de maneira que a oração dela (oração conhecida como Magnificat) traz uma profundeza teológica tão grande. A virtude de Deus envolve 0 "olhar para baixo" de Deus e lá, ver Maria, logo após a exalta, chamando -a de bem-aventurada (LUTERO, 1999, p.12). Lutero entendia que, ao ter o Senhor como exemplo, todo cristão necessitaria sempre ter um "olhar para baixo", valorizando até mesmo os mais pobres. Lutero ainda complementa no seu comentário a respeito da oração de Maria que

[...] ninguém quer olhar para baixo. Lá tem pobreza, desonra, miséria, desgraça e angústia. Todo mundo desvia 0 olhar disso. Todos se afastam de pessoas dessa espécie. Evitam, rejeitam e abandonam essa gente, e ninguém se lembra de lhes ajudar e de trabalhar para que também sejam alguém. [...] Por isso, somente Deus consegue ver as coisas dessa maneira, olhando para baixo, para a miséria e a desgraça. Ele está junto a todos os que estão no fundo do poço, como diz Pedro: "Resiste aos soberbos, aos humildes concede a sua graça" (1 Pedro 5.5). Essa experiência gera 0 amor a Deus $\mathrm{e}$ seu louvor.

Em outro momento, em sua obra que comenta a oração de Maria, Lutero refuta de maneira enérgica a respeito do governo da sua época, ele afirma que 0 governante jamais pode pensar na terra e nas pessoas como propriedade deles, que jamais deve procurar os interesses próprios, mas 0 interesse de seus súditos. Em suma, o governante deveria cuidar das necessidades de seus súditos e agir como se tratasse de suas próprias necessidades (LUTER0, 2000, p.60). Logo, percebe-se que o reformador tinha em mente que a justiça social dependia, e muito, da presença de governantes não dados ao egoísmo e a avareza. Ele afirmava que as pessoas eleitas como representantes do povo têm a função de servir, promover a paz, a justiça e 0 bem-estar de todas as pessoas.

Dentre os estudiosos de Lutero, Westhelle salienta que Karl Marx, ao estudar Lutero, dizia que "a acumulação primitiva [do capital] desempenha na economia política um papel semelhante ao pecado original na teologia." Westhelle (2013, p.330) ao analisar a teologia de Lutero, entende que a política existe para alcançar a justiça econômica. Logo, se a política se recusa a administrar a justiça, a mesma é corrompida.

$\mathrm{Na}$ antropologia de Lutero (2000, p.37), ele considera que ao ser justo e honesto, um governante não presta serviço apenas ao seu povo, mas ao próprio Deus. Ele salientava que na vida ordinária, nas profissões comuns e no labor cotidiano, que a maior parte das pessoas serve e honra a Deus. É, justamente, nas questões práticas da vida, ou seja, na administração do direito e da justiça, que Lutero vê duas possibilidades concretas, a saber, 0 bom senso e 0 amor. Nesse aspecto, ao trazer essas virtudes para a política, os mesmos contribuem para a criação de espaço nas estruturas sociais de modo a prevalecer não a competição desenfreada, mas a reciprocidade, a justiça e a liberdade, condições essas que são basilares para garantir a dignidade de todas as pessoas.

Por fim, Lutero, em sua obra sobre a Política, Fé e Resistência, entende que a ausência de leis e normas sociais justas vão afetar, em última análise, as pessoas mais fracas da sociedade, gerando nas pessoas a necessidade de destruir, assaltar, roubar etc., colocando em perigo a saúde de toda a comunidade. Portanto, ao se brigar pelos direitos dos pobres, por consequência, é gerado, de maneira eficaz, o bem para toda a sociedade. 
Apesar de Lutero levantar questões importantes a respeito da justiça social e a política, foi o reformador João Calvino que trouxe, de maneira bastante prática para 0 dia a dia dos cidadãos comuns, aplicações e conceitos no tocante a justiça social ${ }^{3}$.

\subsection{JOÃO CALVINO}

Enquanto Lutero tinha grande parte dos seus escritos voltados para as autoridades e a responsabilidade deles com os menos favorecidos, 0 grande reformador, João Calvino, tinha seu foco nas pessoas comuns, as quais ele ensinava diariamente. 0 tema da justiça social estava muito presente em seus sermões e nos parágrafos, a seguir, será feito um panorama de como esse reformador abordava a questão do pobre e do necessitado.

Antes de tudo, Calvino (1996, p.125) condena a ociosidade; ele comenta que, em sua perspectiva, Deus ordenou ao homem o cultivo do solo e condenou 0 repouso indolente. Ele acreditava ser "contrário à ordem da natureza do que a vida ser consumida em comer, beber e dormir, enquanto no ínterim nada nos propomos fazer".

A partir de uma cosmovisão a qual o ócio não deve fazer parte do cotidiano do homem, Calvino expõe a sua percepção de amor ao próximo de maneira bastante prática, ou seja, fazendo algo para ajudar os irmãos. Para Calvino ${ }^{4}, 0$ amor nos leva a fazer mais pelo próximo, ninguém deve viver exclusivamente

\footnotetext{
3 Um ponto um tanto quanto controverso na vida de Lutero, dar-se-á no seu documento "Adendo: Contra as Hordas Salteadoras e Assassinas dos Camponeses". Este documento é dirigido às autoridades seculares e cristãs durante a Revolta dos Camponeses na Alemanha, em 1525, com o fim de convencê-las a aniquilarem o movimento revolucionário. Dittrich (2012) afirma que Lutero, antevendo um possível enfrentamento entre os camponeses e as autoridades, busca, numa primeira tentativa, a reconciliação entre as partes através do Documento "Exortação à paz: resposta aos doze artigos do campesinato da Suábia". Não obtendo êxito e constatando 0 avanço das pretensões campesinas, escreve 0 documento "Adendo: contra as hordas salteadoras e assassinas dos camponeses". Lutero fundamenta seus argumentos do uso da força contra os camponeses em alguns preceitos bíblicos: a) Desrespeitam o juramento de fidelidade e reverência que prestaram a Deus e às autoridades: Dai a César o que é de César; Todo homem esteja sujeito às autoridades superiores; b) Promovem rebelião: assaltam e saqueiam conventos e castelos que não lhes pertencem; c) Acobertam seu pecado com o Evangelho: Iouvam e servem ao diabo sob as aparências do Evangelho; dizem-se irmãos cristãos e obrigam as pessoas a acompanharem suas barbaridades.

4 João Calvino, Efésios, (Ef 4.28), p. 146.
}

para si mesmo e negligenciar o próximo, pelo contrário, todos devem devotar à ação de suprir as necessidades do outro.

Outro conceito interessante na perspectiva de Calvino (1996, p. 225-228) era a respeito da distinção entre 0 "empréstimo de consumo e 0 empréstimo de assistência". No seu modo de entender, o empréstimo que visava socorrer pessoas necessitadas e famintas, não são dignos de cobranças de juros, por outro lado, 0 empréstimo 0 qual 0 devedor pudesse adquirir uma ampliação de seus recursos, ou seja, tenha benefício com seus negócios, a compensação pelo recurso emprestado é devida.

A ortopraxia ${ }^{5}$ de Calvino era invejável, em seu comentário a respeito do capítulo XV do livro de Salmos ${ }^{6}$, ele afirma que todos devem se precaver de, engenhosamente, inventar pretextos para tirar proveito de seus semelhantes, e, pior ainda, acreditar que qualquer coisa pode ser lícita quando para os outros é algo grave e prejudicial.

A maneira a qual em sua exposição de 2 Coríntios, Calvino (1995, p.177) aconselha que aqueles que têm riquezas devem lembrar que "0 excedente não deve ser usado para intemperança ou luxúria, mas para aliviar as necessidades dos irmãos". Ele faz um paralelo ao maná, que era acumulado como excesso de ganância ou falta de fé, logo 0 indivíduo "não devemos alimentar dúvidas de que as riquezas que são acumuladas à expensa de nossos irmãos são malditas, e logo perecerão". Por consequência, a partir do texto supracitado, entende-se que ele não conseguia imaginar que a forma de uma pessoa abastada crescer seria fazendo provisões para um futuro distante $\mathrm{e}$ defraudando os mais pobres da ajuda que é devida.

Calvino ainda ratifica em sua interpretação do livro de Hebreus, capítulo 13 que 0 fato de não amar 0 próximo constitui-se numa ofensa a Deus e às pessoas. Em contraposição, o auxílio recíproco revela a unidade do Espírito Santo entre os cristãos. Em um excerto extraído da sua exposição de Hebreus ${ }^{7}$ :

Não é uma honra trivial o fato de

\footnotetext{
5 Enquanto a ortodoxia é o ensino correto da doutrina, a ortopraxia é a prática correta da mesma.

6 João Calvino, 0 Livro dos Salmos, Vol. 1, (SI 15.5), p. 297-298.

7 João Calvino, Exposição de Hebreus, São Paulo: Paracletos, 1997, (Hb 13.16), p. 394.
} 
Deus considerar o bem que fazemos aos homens como sacrifício oferecido a Ele próprio, e o fato de valorizar tanto nossas obras, que as denomina de santas. Portanto, onde nosso amor não se manifesta, não só despojamos as pessoas de seus direitos, mas também a Deus mesmo, 0 qual solenemente dedicou a $\mathrm{Si}$ o que ordenou fosse feito em favor dos homens.

Repartir com os outros' tem uma referência mais ampla do que fazer o bem. Inclui todos os deveres pelos quais os homens se auxiliam reciprocamente; e é um genuíno distintivo do amor que os que se encontram unidos pelo Espírito de Deus comunicam entre si.

Portanto, fica claro que, em todo o tempo, esse reformador traz um tom prático e pastoral nos seus ensinos, para ele a profissão de fé não pode estar desvinculada a demonstração de justiça para com os mais necessitados. Ainda sobre a vida de Calvino, André Biéler (2012, p.229-230) afirma que

\footnotetext{
"[...] a pregação do reformador é 0 prolongamento de sua ação. A modéstia em que vive com seus colegas é proverbial e toca as raias da pobreza. Suas providências em favor dos deserdados são constantes. Importuna persistentemente os conselheiros da cidade para que tomem medidas de atendimento aos pobres. Depois da chacina dos protestantes em Provence, em 1545, organiza pessoalmente uma coleta geral, subindo as escadarias dos edifícios repletos de refugiados para recolher a esmola de todos".
}

\section{A IGREJA CONTEMPORÂNEA E A JUSTIÇA SOCIAL}

Até esse momento, foram analisadas as afirmações a respeito da justiça social nos escritos bíblicos, desde o livro de Gênesis, até os discursos dos reformadores que tiveram maior destaque no século XVI, é salutar, portanto, uma análise da igreja contemporânea no Brasil e, em especial, as de vertente protestante, herdeiras diretas dos ensinos teólogos medievais.

Há um teólogo moderno, Karl Barth (1981), que afirma que a teologia evangélica tem a função de formular uma pergunta concernente à verdade, ou seja, o teólogo tem a missão de inquirir se a igreja está compreendendo e comunicando (através do seu discurso e prática) corretamente 0 evangelho. 0 fato é que 0 teólogo, como formador de conteúdo, tem sempre defendido a maneira correta que deve ser transmitida a sã doutrina, apontando, por consequência, a melhor prática da mesma. Não é encontrado, em nenhum escrito dos teólogos modernos, algo que ensine ao contrário de tudo o que foi defendido até aqui, tanto pela Bíblia, quanto pelos reformadores. Entretanto, se parte considerável da população que tem como norma de fé e prática as sagradas escrituras e, conforme dito anteriormente, ensina a respeito da justiça social e da assistência aos menos favorecidos, qual seria 0 motivo que ainda se encontra tanta miséria na população brasileira?

Como é inviável analisar todas as Igrejas Evangélicas do país e a atuação de cada uma delas individualmente, neste trabalho, optou-se por pesquisar as consequências dos segmentos mais relevantes em sua ortopraxia. Foram analisados três principais vertentes protestantes, a saber, protestantismo de imigração, as denominações históricas e as igrejas de vertente pentecostal ${ }^{8}$, conforme relatado a seguir. Foram usados, para a comparação das três vertentes protestantes, os estudos provenientes de Elizete da Silva (1996) tratando dos dois primeiros grupos e Claudia Silva (2009) ao falar sobre os pentecostais.

\subsection{IGREJAS DO PROTESTANTISMO DE IMIGRAÇÃO E DENOMINAÇÕES HISTÓRICAS}

Elizete da Silva (1996) analisa essas duas denominações e como elas se posicionaram frente aos

\footnotetext{
$8 \mathrm{Na}$ análise das igrejas de vertente protestante não foram analisadas as neopentecostais separadamente, pois segundo Souza (2017, p.35), o surgimento das igrejas neopentecostais nada mais é do que uma vertente para-eclesiástica proveniente dos pentecostais, diferindo, apenas, pelo fato da ausência dos usos e costumes fortemente imposto pelos pentecostais, em seus primórdios. Logo, a análise feita para os pentecostais, por definição, aplica-se ao grupo neopentecostal.
} 
problemas sociais que afligiram o país, seu relacionamento com a sociedade circundante situada além dos muros da igreja e, por fim, que representações foram construídas para tornar as relações plausíveis para seus fiéis e a população em geral. Em sua conceituação, ela define que, na tipologia do protestantismo brasileiro, luteranos e anglicanos se identificam com 0 tipo protestantismo de imigração, já as denominações tidas como protestantismo missionário, são as denominações históricas: congregacionais, presbiterianas, metodistas e batistas.

Ao analisar o impacto do primeiro grupo, ou seja, os luteranos e anglicanos, Silva (1996) informa que as denominações ligadas à imigração, durante muito tempo apenas trabalharam numa comunidade fechada em si não se importando com os problemas ou a vida social no Brasil: faziam o culto em sua própria língua e, também, facilitavam a entrada de novos imigrantes no país. Basicamente, toda e qualquer atividade era voltada "para os de dentro", ou seja, qualquer prática de justiça ficava baseada dentro de um próprio nicho cultural, deixando de lado os necessitados que nasceram em terras tupiniquins. Conforme lembra a autora, havia "um verdadeiro distanciamento das questões nacionais" e que, apenas a partir da década de 60 que a Igreja Evangélica de Confissão Luterana passou a ter uma preocupação efetiva com as questões pertinentes à realidade brasileira.

0 grupo das denominações históricas, de acordo com Silva (1996), agiu de maneira completamente diferente do primeiro grupo. Desde a década de 90 do século XIX que as igrejas já haviam estabelecidos igrejas e colégios para toda a população brasileira. Entretanto, devido à forte influência pietista e uma visão fundamentalista do texto bíblico, essas igrejas dividiam a sociedade entre 0 reino de Deus (os protestantes) e o reino do mal que está sob o domínio do pecado e das forças satânicas, considerando, portanto, que 0 cristão deve afastar-se completamente desse mundo, renegá-lo como criação do diabo e seus agentes. De maneira geral, a máxima pietista e individualista que permeava a ética social do protestantismo brasileiro na sua primeira fase era de "conver- ta-se 0 homem e a sociedade se transformará". Em outras palavras, os problemas sociais como a fome, a miséria e a corrupção são considerados frutos do pecado individual, portanto a solução está por meio da mensagem evangélica que atinge e transforma as almas e não com um programa político-estrutural para a sociedade.

Contudo, Silva (2009) afirma que foi a partir de meados do século XX que teólogos e intelectuais das igrejas históricas voltaram seus olhos para as "coisas do mundo", ou seja, os problemas sociais. Que, segundo ela,

Esse novo olhar para as necessi-
dades sociais de homens e mu-
Iheres exigiu a elaboração de uma
teologia que avaliasse e compre-
endesse as condições materiais e
espirituais da sociedade, dando
origem à denominada Teologia
da Missão Integral da Igreja, cujo
propósito era a atenção à evan-
gelização e à ação social.

\subsection{IGREJAS PENTECOSTAIS}

Já no ramo pentecostal, alguns autores se destacam ao estudar a justiça social nesse meio. Em especial, a Dra. Claudia Silva, no ano de 2009, em seu artigo "As ações assistenciais promovidas pelas igrejas pentecostais: motivações e dificuldades" tem seu foco em apenas uma pequena vertente da justiça social, entretanto as conclusões chegadas por ela são de grande valia. Uma característica marcante salientada pela autora é que "a teologia pentecostal prevê tãosomente a força e a ação do Espírito Santo para a superação dos problemas." 0 que pode levar a crer que a práxis neste meio não está muito presente. Contudo, na verdade, não foi o que ela constatou em seu estudo.

Silva (2009) entende que a concepção de pobreza no meio pentecostal "decorre de uma situação individual, tanto de quem tem mais, porque movido pelo egoísmo, [...] quanto do que nada tem, porque uma força fora deste mundo, maligna, o estaria impedindo de prosperar [...]". Logo, nessa cosmovisão, somente pela fé em Deus e Jesus seria possível superar 
a força que estaria dominando a vida do crente. Silva (2009) ainda afirma que 0 crescimento das denominações pentecostais se deu, preferencialmente, nas camadas mais pobres da população, logo

As igrejas, de modo geral, não adotam como política de ação a criação e manutenção de instituições socioassistenciais, ou mesmo 0 incentivo para seus membros desenvolverem atividades assistenciais. São ações motivadas por princípios e valores dos dirigentes espirituais que, sensibilizados com a situação de pobreza daqueles que se encontram ao seu redor, partem para ações mais sociais, justificando suas motivações como uma determinação bíblica para amparar os mais pobres.

A partir daí, Silva (2009) entende que há uma dificuldade, dentro da vertente pentecostal, em não praticar proselitismo e a defesa dos direitos sociais, visto que eles não caminham na mesma estrada. Ela entende que, quando os caminhos se cruzam, fica evidente 0 conflito, uma vez que essas concepções são distintas e tem pouca possibilidade de se conciliarem. Logo, as igrejas têm como atividade prioritária orar e louvar a Deus e, quando decidem pôr em prática a caridade os problemas começam a se manifestar, principalmente quando se decide criar instituições assistenciais.

\section{CONSIDERAÇÕES FINAIS}

Tanto nos escritos quanto veterotestamentários, indubitavelmente, a Bíblia descreve como uma necessidade e uma ordem, a justiça social e, por consequência, a assistência aos mais necessitados. Desde o livro de Gênesis é visto como, em suas prescrições, Deus enfatiza a necessidade do olhar atento ao outro. Conforme mencionado no artigo, uma das principais características na literatura do antigo testamento é que as histórias eram contadas de geração em geração para, em um determinado momento, ser transcrita em rolos ou pergaminhos. Portanto, concluímos que, se nesse inconsciente popular as lições transmitidas de pais para filhos preservam-se 0 cuidado ao mais necessitado, por consequência, entende-se que esse preceito foi muito importante na história dos judeus. Por fim, fica claro que, na mentalidade do povo hebreu, era impossível adorar a Deus se meu irmão passa necessidade.

No Novo Testamento, os preceitos aparecem de maneira ainda mais intensa, visto que a vida em comunidade e as perseguições sofridas pela igreja primitiva só reforçava a necessidade do cuidar do outro. 0 carpinteiro de Nazaré comparou 0 cuidar e acolher "os pequeninos" como cuidar e acolher a ele próprio, enfatizando, desta maneira, a observância desse mandamento.

Já ao analisar a vida e obra dos principais reformadores, Lutero e Calvino entendem que 0 ensino dos mesmos ratificava a importância das práxis cristãs na luta para o fim de toda e qualquer injustiça. Havia, contudo, uma grande diferença na abordagem desse conceito na vida dos dois: Lutero tinha seu enfoque de aplicação da justiça social a partir da atuação de políticos. Ele entendia que, dado o poder e autoridade outorgada aos governantes, eles tinham a obrigação de criar leis e iniciativas que minimizassem o sofrimento e toda e qualquer injustiça sofrida pelo povo. Ao passo que Calvino, apesar de lutar pela desigualdade, tinha seu enfoque na vida cotidiana do "homem simples", com atitudes práticas e exposições bíblicas aplicadas à realidade cotidiana com conselhos simples que levariam a condutas diárias a favor da justiça social. Ou seja, em seus sermões e em seus escritos, Calvino enfatizava a necessidade de ajudar os mais necessitados, entretanto, em sua visão, esse auxílio deveria partir da conduta diária de cada cristão, não terceirizando essa responsabilidade a nenhum órgão ou setor da sociedade.

Por fim, ao considerar as três vertentes mais representativas no cenário do evangelicalismo brasileiro, percebeu-se que as interpretações e os enfoques institucionais prevaleceram em contraponto aos ensinamentos bíblicos. Na primeira vertente aborda- 
da, o protestantismo de imigração (representado pelos luteranos e anglicanos), tinha 0 seu enfoque nos imigrantes, afunilando sua área de atuação naqueles que chegavam ao Brasil provenientes de nações-mãe das próprias igrejas. Portanto, havia, claramente, uma preferência pelo necessitado que tinha algum vínculo com as raízes da congregação, ao passo que os demais brasileiros ficavam em segundo plano e não faziam parte do seu interesse primeiro.

0 protestantismo histórico (representado peIos congregacionais, presbiterianas, batistas e metodistas), devido à influência do pietismo, se separava do que era tido como secular, criando um nicho de atuação entre os próprios cristãos, isolando-se das atividades e pessoas tidas como "mundanas". Houve, entretanto, uma mudança apenas com o surgimento da Teologia da Missão Integral que, grosso modo, começou a trazer de volta os conceitos da imago dei e considerando que a mensagem do evangelho é uma mensagem integral, atuando em todas as áreas da vida do ser humano, não apenas no que era tido como transcendente, levando, assistência aos necessitados, aceitando ou não a mensagem de boas novas, trazida por eles.

Por fim, a última vertente evangélica analisada foram os pentecostais que, de maneira bastante peculiar, apresentaram maiores dificuldades em seguir tanto os preceitos bíblicos quanto os ensinamentos dos reformadores, deixando de atuar na luta pela justiça social. A grande fraqueza desse grupo deu-se pela dificuldade de separar o proselitismo da luta pelo bem social (independente da questão de fé), uma vez que entende que o mal que acontece com o indivíduo é por uma ação puramente maligna e espiritual. Em outras palavras, para que a dor e o sofrimento alheio sejam sanados, é necessário que ele compactue com as mesmas crenças que eu, caso contrário, o mal que ele vive é decorrente aos seus próprios pecados e pela ausência de busca pelo Deus que supre as necessidades.

$5.17)$.

\section{REFERÊNCIAS}

BALANCIN, E. M. História do Povo de Deus. 7. ed. São Paulo: Paulus, 1989.

BARTH, K. Evangelical Theology: An Introduction. New York: Eerdmans, 1963.

BÍBLIA, Português. Bíblia de Estudo NVI. Tradução: Nova Versão Internacional. São Paulo, SP: Vida, 2003.

BIÉLER, A. 0 Humanismo Social de Calvino. 2. ed. São Paulo: Cultura Cristã, 2012.

CALVIN, J. Commentaries on The First Book of Moses Called Genesis. Grand Rapids, Michigan: Eerdmans Publishing Co., 1996.

CALVIN, J. Calvin's Commentaries, Grand Rapids, Michigan: Baker Book House Company, 1996.

CALVIN, J. Exposição de 2 Coríntios, São Paulo: Paracletos, 1995.

DITTRICH, I. J. 0 discurso de Lutero contra os camponeses: retórica da ação. Antares, v.4, n. 8, p. 111124, jul./dez. 2012

KELLER, T. Justiça Generosa: a graça de Deus e a Justiça Social. Tradução Eulália Pacheco Kregness. São Paulo, SP: Vida Nova, 2013.

LUTERO, M. Política, fé e resistência: da autoridade secular, até que ponto se the deve obediência (1523). São Leopoldo: Sinodal; Porto Alegre: Concórdia, 2000.

LUTERO, M. 0 louvor de Maria (0 Magnificat) (1521). São Leopoldo: Sinodal; Porto Alegre: Concórdia, 1999.

MACKAY, J. A., A Preface to Christian Theology. New York: Macmillan, 1941.

MILHORANZA, A. S. Amós: 0 Profeta da Justiça Social. Disponível em: <http://www.milhoranza. com/2013/05/24/antigo-testamento-amos/\#.WjF_ PFWnFaR>. Acesso em: 12 jul. 2017 
PADILHA, R. Hermenutics and Culture, Down to Earth: Studies in Christianity and Culture. Grand Rapids: Eerdmans, 1980.

PASSARELLA, J. B. Justiça Social na Bíblia: 0 Deus que se revela aos pobres. Curitiba: Appris, 2014.

ROCHA, C. T. Responsabilidade Social da Igreja. Londrina: Descoberta, 2003.

SANTOS, B. de S. If God Were a Human Rights Activist: Human Rights and the Challenge of Political Theologies. Law, Social Justice \& Global Development Journal (LGD), v. 1, n. 13, 2009.

SHEDD, R. P. Justiça Social e a interpretação da Bíblia. 2. ed. São Paulo: Vida Nova, 2013.

SILVA, C. N. As ações assistenciais promovidas pelas igrejas pentecostais: motivações e dificuldades. Estudos de Religião, v. 23, n. 36, 35-60, jan./jun. 2009.

SILVA, E. da. Protestantismo e questões sociais. Sitientibus, n.14, p.129-142, 1996.

SOUZA, C. A. M., 0 impacto apostólico: 0 papel do apóstolo na construção do Reino de Deus. Rio de Janeiro: Thomas Nelson Brasil, 2017.

WESTHELLE, V. Poder e política: incursões na teologia de Lutero. In: HELMER, C. (Ed.). Lutero: um teólogo para tempos modernos. São Leopoldo: Sinodal, EST, 2013.

Recebido em: 10/03/2018

Aceito em: 13/06/2018 